\title{
MAKNA DAN FUNGSI SARAFAL ANAM DALAM ACARA PERNIKAHAN SUKU LEMBAK DI KELURAHAN PAGAR DEWA KECAMATAN SELEBAR KOTA BENGKULU
}

\author{
Jelita Zakaria ${ }^{1}$ dan St. Asiyah ${ }^{2}$ \\ FKIP Universitas Muhammadiyah Bengkulu \\ jelitazakaria12@yahoo.com; st.asiyah@umb.ac.id
}

\begin{abstract}
Abstrak
Manusia merupakan makhluk yang berbudaya.Melalui akalnya manusia dapat mengembangkan kebudayaan. Begitu juga manusia hidup dan tergantung pada kebudayaan sebagai hasil ciptaannya. Olek karena itu kebudayaan mempunyai fungsi yang besar bagi manusia dan masyarakat. Suku Lembak adalah salah satu suku yang ada di Provinsi Bengkulu.Masyarakat Suku Lembak kaya dengan budaya dan sastra lisan. Seni pertunjukan Sarafal Anam merupakan salah satu budaya masyarakat Lembak yang masih hidup di tengah-tengah masyarakat Lembak.Perlu diketahui bahwa budaya pertunjukan Sarafal Anam yang dimiliki oleh masyarakat suku Lembak khususnya di Kelurahan Pagar Dewa Kecamatan Berdasarkan hasil analisis data dan pembahasan penulis simpulkan bahwa pertunjukan seni Sarafal Anam bagi masyarakat suku Lembak pada acara pernikahan di kelurahan Pagar Dewa Kota Bengkulu memiliki makna solidaritas, kebersamaan, dan hiburan sebagai pelengkap kegembiraan terwujudnya pernikahan anak dalam suatu keluarga. Melalui seni pertunjukan Sarafal Anam nilai budaya yag terkait dengan solidaritas dan kebersamaan akan selalu terpupuk dengan baik. Khusus bagi pemyelenggara, pelaksanaan pertunjukan seni Sarafal Anam yang mereka selenggarakan adalah secara tidak lansung untuk memberitahukan kepada masyarakat lingkungan bahwa anak yang akan menikah adalah bujang dan gadis. Pertunjukan seni Sarafal Anam pada acara pernikahan masyarakat suku lembak di Kelurahan Pagar Dewa Kota Bengkulu juga memiliki beberapa fungsi, yaitu (1) sebagai hiburan, (2) fungsi pendidikan, (3) fungsi penebal emosi keagamaan, (4) fungsi estetis. Fungsi tersebut melekat pada unsur pokok dalam proses penyelenggaraan Sarafal Anam, yaitu pemeran, penyelenggara dan penonton.
\end{abstract}

\section{Kata kunci: Sarafal Anam, Makna, dan Fungsi}

\begin{abstract}
Humans are cultured creatures. Through reason, humans can develop culture. Likewise humans live and depend on culture as a result of their creation. Therefore, culture has a great function for humans and society. The Lembak tribe is one of the tribes in Bengkulu Province. The Lembak people are rich in culture and oral literature. Sarafal Anam performance art is one of the Lembak community culture that still lives in the middle of Lembak community. Please note that the Sarafal Anam performance culture owned by the Lembak tribe community, especially in Pagar Dewa Subdistrict Based on the results of data analysis and the writer's discussion, concludes that the art performance Sarafal Anam for the Lembak tribe community at a wedding in the village of Pagar Dewa Bengkulu City has a meaning of solidarity, togetherness, and entertainment as a complement to the joy of the realization of child marriage in a family. Through Sarafal Anam's performing arts, cultural values related to solidarity and togetherness will always be fostered well. Especially for the organizers, the implementation of the Sarafal Anam art performance that they held was indirectly to inform the neighborhood community that the children to be married were single and girl. The performance of Sarafal Anam art at a wedding of a tribal community in Pagar Dewa, Bengkulu City also has several functions, namely (1) as entertainment, (2) education function, (3) religious emotional thickening function, (4) aesthetic function. The function is attached to the main elements in the process of organizing Sarafal Anam, namely the cast, organizer and audience.
\end{abstract}

Keywords: Sarafal Anam, Meaning, and Function

\section{PENDAHULUAN}

Kebudayaan merupakan hal yang esensial dalam kehidupan manusia. Kebudayaan adalah suatu keseluruhan kompleks yang meliputi pengetahuan, kepercayaan, kesenian, moral, keilmuan, hukum, adat istiadat, dan kemampuan yang lain serta kebiasaan yang didapat oleh manusia sebagai anggota masyarakat Tylor (dalam Setiadi dkk, 2012). Sejalan dengan tata pikir dan sikap tindak 
lanjut perkembangan hidup manusia, maka kebudayaan mengandung nilai-nilai dan norma-norma kehidupan yang berlaku dalam tata cara pergaulan masyarakat.

Peran dan fungsi kebudayaan daerah seiring dengan perkembangan dan perubahan yang terjadi pada setiap aspek kehidupan masyarakat. Kebudayaan daerah sebagai kekayaan budaya bangsa merupakan salah satu bentuk ekspresi dan kreasi masyarakat daerah yang sangat berharga. Kebudayaan daerah tidak hanya menyimpan nilai-nilai budaya dari suatu masyarakat tradisional, tetapi juga menjadi akar budaya bangsa. Kebudayaan mempunyai fungsi yang besar bagi manusia dan masyarakat. Dalam menjalani kehidupan, berbagai macam kekuatan harus dihadapi manusia dan masyarakat, seperti kekuatan alam dan kekuatan lainnya. Selain itu manusia dan masyarakat memerlukan kepuasan baik secara spiritual maupun material.

Provinsi Bengkulu, merupakan salah satu provinsi di Indonesia yang memiliki keberagaman suku bangsa. Salah satu suku yang ada di Provinsi Bengkulu adalah suku Lembak yang sebagian besar menduduki wilayah kota. Masyarakat Suku Lembak kaya dengan budaya dan sastra lisan. Namun sebagian sudah mulai hilang dari tengah-tengah kehidupan masyarakat suku Lembak. Dari pengamatan penulis, kebudayaan yang masih dilaksanakan sampai sekarang adalah pertunjukan Sarafal Anam.

Ratna (dalam Jauhari, 2018) mengatakan setiap aktivitas kebudayaan apabila difungsikan secara baik dengan sendirinya memiliki makna. Makna adalah sebagai penghubung bahasa dengan dunia luar yang sesuai dengan kesepakatan sehingga dapat saling mengerti. Pengkajian makna Sarafal Anam diarahkan pada hubungan antara lantunan syair-syair SarafalAnam dengan masyarakat pendengarnya. Jadi sebuah pertunjukan Sarafal Anam tidak hanya dilihat dari aspek budaya saja tetapi juga bisa dari aspek yanglain seperti aspek sosial dan aspek keagaman.

Pada hakekatnya seni pertunjukan adalah gerak, perubahan keadaan. Oleh karena itu substansinya terletak pada imajinasi serta proisesnya seni pertunjukan daerah di Indonesia berangkat dari suatu keadaan di mana ia tumbuh. Seni pertunjukan akan tumbuh dalam lingkungan etnik yang berbeda satu sama lain. Pertunjukan Sarafal Anam biasanya dilakukan pada acara aqikah dan acara pernikahan. Puncak dari pertunjukan Sarafal Anam adalah lantunan syair-syair berzanji yang diiringi dengan tabuhan rebana. Pelaksanaan Sarafal Anam terdiri dari unsur syair berzanji, pemeran, tempat, alat, dan penonton. Pertama pemeran, yaitu orang yang memainkan alat baik sebagai pembaca syair maupun sebagai penabuh rebana. Masing-masing pemeran baik sebagai pembaca syair maupun penabuh gendang atau rebana, dipimpin oleh seorang yang ditujuk untuk memimpin acara pertunjukan Sarafal tersebut. Yang bertindak sebagai pemeran adalah kaum lakilaki yang sudah berkeluarga (bapak-bapak). Kedua, tempat yang digunakan untuk melaksanakan pertunjukan Sarafal Anam yaitu tarub yang sudah disiapkan oleh yang mempunyai hajatan dan 
dibantu oleh masyarakat lingkungan di mana pertunjukan Sarafal Anam tersebut di adakan. Ketiga penonton, yaitu masyarakat yang menyaksikan. Penonton ini terdiri dari berbagai tingkatan usia.

Bagi masyarakat suku Lembak, pelaksanaan Sarafal Anam bertujuan sebagai ucapan syukur terlaksananya pernikahan. Syarafal Anam merupkan budaya yang di dalamnya mengandung banyak hal yang dapat diambil hikmah dan manfaatnya baik secara religius maupun sosial masyarakat. Hal ini sejalan dengan pendapat Setiadi dkk (2012) bahwa budaya yang dikembangkan oleh manusia akan berimplikasi padalingkungan tempat kebudayaan itu berkembang. Suatu kebudayaan memancarkan suatu ciri khas dari masyarakatnya.

Perlu diketahui bahwa budaya pertunjukan Sarafal Anam yang dimiliki oleh masyarakat suku Lembak khususnya di Kelurahan Pagar Dewa Kecamatan Silebar Kota Bengkulu kurang mendapatkan perhatian bagi generasi muda. Sepertinya mereka kurang tertarik untuk mempelajarinya. Bahkan saat ini yang bisa memainkan dan melantunkan Syair Sarafal Anam hanya generasi yang sudah tua dan jumlahnyapun sedikit. Dikhawatirkan, kalau tidak dikenalkan kepada generasi muda maka ia akan punah.

Oleh karena itu berbagai usaha harus dilakukan untuk melestarikan budaya Sarafal Anam baik memperkenalkannya kepada generasi muda, maupun kepada masyarakat luar selain masyarakat Lembak yang ada di Kelurahan Pagar Dewa Kota Bengkulu.

\section{METODE PENELITIAN}

Metode yang digunakan dalam penelitian ini adalah penelitian deskriptif kualitatif. Dengan menggunakan metode deskriptif kualitatif diharapkan penelitian menghasilkan uraian atau deskriptif tentang seluk beluk makna dan fungsi Sarafal Anam di Kelurahan Pagar Dewa Kecamatan Silebar Kota Bengkulu Provinsi Bengkulu

\section{HASIL PENELITIAN DAN PEMBAHASAN}

Seni Sarafal Anam merupakan, salah satu kesenian daerah yang dimiliki oleh masyarakat Suku Lembak . Pertunjukan Sarafal Anam ini biasanya dilakukan pada acara aqikah dan acara pernikahan. Seni Sarafal Anam menitik beratkan pada cerita yang diproyeksikan pada audiens. Seni Sarafal Anam ini dibawakan dengan lagu khas serta dan diiringi dengan tabuhan rebana. Cerita yang dibawakan adalah cerita sejarah latar belakang keturunan, dan sifat-sifat terpuji yang dimiliki Nabi Muhammad SAW.

Pertunjukan dilakukan pada malam hari sesudah akad nikah, dari jam 19.30 sampai jam 02.00 WIB dan dilanjutlan keesokan harinya dari jam 08.00 sampai jam 10.00 WIB. Peserta pertunjukan hanya laki-laki yang mempunyai kemampuan untuk berzikir dan membaca syair berzanji. 


\section{Makna Pertunjukan Sarafal Anam bagi Masyarakat Lembak}

Seni pertunjukan Sarafal Anam merupakan, salah satu kesenian daerah yang dimiliki oleh masyarakat Suku Lembak. Pertunjukan Sarafal Anam ini biasanya dilakukan pada acara aqikah dan acara pernikahan.Seni Sarafal Anam ini dibawakan dengan lagu khas serta diiringi dengan tabuhan rebana. Syair yang dilantunkan dalam pertunjukan Sarafal Anam, dilatarbelakangi dengan cerita sejarahdan sifat-sifat terpuji yang dimiliki Nabi Muhammad SAW.

Menurut Rahardi (2006) persoalan makna menarik untuk dikaji. Beliau mengatakan, mengkaji makna tidak bisa tidak harus dikaitkan dengan aspek-aspek referensial dan sosiokultural yang menjadi indeksnya. Artinya konteks perlu dihadirkan ketika kita mengkaji suatu makna. Dalam suatu seni pertunjukan, konteksnya adalah lingkup sosial budaya dimana seni pertunjukan tersebut tumbuh dan berkembang.

Makna pertunjukan seni Sarafal Anam dalam acara pernikahan Suku Lembak di Kelurahan Pagar Dewa Kota Bengkulu, dapat dikaji dari unsur yang terlibat dalam proses pertunjukan pelaksanaan Sarafal Anam itu sendiri, yaitu pemeran, penyelenggara maupun penonton. Pemeran adalah orang yang memberikan suguhan pertunjukan berupa seni bahasa melalui lantunan syairsyair Arab yang dilagukan yang diiringi dengan tabuhan rebana. Penyelenggara adalah tuan rumah yang melaksanakan pertunjukan Sarafal Anam untuh memeriahkan acara pernikahan anak mereka. Sedangkan penonton adalah orang-orang yang hadir, secara lansung menyaksikan pertunjukan Sarafal Anam.

Dilihat dari segi pemeran, ada beberapa makna yang bisa ditangkap dalam pertunjukan seni Sarafal Anam dalam acara pernikahan suku Lembak di Kelurahan Pagar Dewa Kota Bengkulu. Makna yang pertama adalah solidaritas dan kebersamaan. Pemeran dalam melakukan pertunjukan seni Sarafal Anam tidak mendapat imbalan. Mereka dengan iklas melakukan pertunjukan Sarafal Anam tersebut. Apa yang dilakukan oleh pemeran adalah semata-mata karena adanya rasa kebersamaan terhadap yang memiliki hajatan. Rasa kebersamaan itu juga ditopang dengan solidaritas yang tinggi sehingga munculah sifat kegotong-royongan yang sudah membudaya dalam masyarakat suku Lembak. Makna yang ke dua adalah melalui lantunan syair-syair dalam pertunjukan seni Sarafal Anam, pemeran juga secara tidak lansung ikut mendoakan semua masyarakat khususnya masyrakat Lembak agar selalu dibersihkan dari perangkap hawa nafsu, diberi kesadaran untuk selalu berbuat baik dan terhindar dari berbagai bencana.

Selanjutnya bagi penyelenggara, pelaksanaan pertunjukan seni Sarafal Anam memiliki makna yang sangat penting yaitu sebagai penentu bahwa anak yag diselenggarakan pernikahannya dengan pertunukan seni Sarafal Anam ini menandakan anak tersebut merupakan bujang dan gadis 
dan trdisi Sarafal Anam ini merupakan pelengkap kebahagiaan mereka. Jadi melalui pertunjukan Sarafal Anam ini, secara tidak lansung keluarga membritahukan kepada masyarakat bahwa anak yang dinikahkan merupakan bujang dengan gadis yang diharapkan nantiya menjadi kelurga yang sakinah. Melalui syair-syair yang dilantunkan dalam pertunjukan Sarafal Anam, semua keluarga berharap anaknya mengikuti apa yang disunahkan oleh Nabi Muhammad SAW, dan menjadikan Nabi Muhammad sebagai teladan dalam menjalani kehidupan.

Selanjutnya penonton menyaksikan pertunjukan Sarafal Anam adalah suatu hiburan yang memupuk rasa kebersamaan dan menunjukan rasa kepedulian terhadap tradisi mereka. Menghadiri undangan merupakan kewajiban bagi mereka sebagai umat Islam.

\section{Fungsi Sarafal Anam Bagi Masyarakat Lembak}

Ratna (dalan Jauhari, 2018: 177) mengatakan setiap aktivitas kebudayaan memiliki fungsi. Apabila kebudayaan tersebut difungsikan dengan baik maka kebudayan tersebut dengan sendirinya memiliki makna. Begitu juga dengan seni pertunjukan Sarafal Anam’

Berdasarkan hasil penelitian pertunjukan seni Syarafal Anam di Kelurahan Pagar Dewa Kota Bengkulu memiliki beberapa fungsi yaitu (1) sebagai hiburan, (2) fungsi pendidikan, (3) penebalan emosi dan keagamaan, (4) fungsi estetis, fungsi tersebut melekat pada unsur pokok dalam proses penyelenggaraan Sarafal Anam, yaitu pemeran, penyelenggara dan penonton.

Pertunjukan seni Syarafal Anam ini merupakan lantunan syair-syair Arab yang diiringi dengan tabuhan rebana. Dengan lantunan syair-sair tersebut suasana menjadi meriah dan penontonya menjadi senang semua tamu yang hadir merasa terhibur. Pada kesempatan ini tentu banyak tamu-tamu yang datang termasuk sanak saudara baik yang jauh maupun yang dekat mereka itu pun merasakan kegembiraan bersama-sama.

Dalam seni pertunjukan Sarafal Anam juga ditemukan nilai-nilai luhur yang pantas untuk dipedomani. Nilai-nilai tersebut adalah solidaritas dalam masyarakat, kedisiplinan, gotong royong, dan juga nilai-nilai agama yang perlu kita pahami dan dapat dijadikan sebagai alat untuk mendidik masyarakat dalam menjalani kehidupan sebagai umat beragama. Fungsi pendidikan melalui kegiatan pertunjukan Sarafal Anam ini dapat dilakukan secara terus menerus oleh masyarakat suku Lembak yang ada di Kota Bengkulu, tentu saja dengan selalu membuadayakan Pertunjukan seni Sarafal Anam.

Pertunjukan seni Sarafal Anam Pada hakekatnya adalah melantunkan syair-syair oleh pemeran dan diiringi dengan tabuhan rebana. Syair-syair yang dilantunkan tersebut bercerita tentang kisah Nabi Muhammat SAW mulai lahir sampai pada kehidupan dewasa. Syair-syair yang dilantunkan oleh pemeran Sarafal Anam tersebut juga banyak bercerita tentang perilaku Nabi Muhammad SAW dalam menjalankan kehidupannya di masyarakat. Kepribadian Nabi Muhammad 
SAW yang diceritakan dalam Syair yang dilantunkan saat pertunjukan Sarafal anam ini merupakan nilai-nilai pendidikan yang perlu diteladani dalam menjalani kehidupan baik di rumah tangga mapun di lingkungan masyarakat. Artinya melalui pertunjukan Sarafal Anam, baik penonton, penyelenggara maupun pemeran mendapatkan pendidikan yang sangat berharga dalam menjalani kehidupan agar menjadi manusia yang lebih baik.

Syair Sarafal Anam berisikan selawat dan kisah Nabi Muhammad. Sebagai umat yang taat akan ajaran kita wajib brselawat semoga kita mendapat safaatdi yaumul mahsyar nanti. Di samping itu dengan melantunkan syair-syair Sarafal Anam, berarti kita juga sudah melakukan dakwah, karena syair Sarafal Anam ini sebagian adalah pujian dan kalimat tayyibah yang dibawa oleh Nabi Muammad SAW sebagai pautan umat Islam.Selanjutnya syair-syair yang dilantunkan dalam pertunjukan Sarafal Anam juga menceritakan tentang perjuangan Nabi Muhammad dalam menyebarkan Agama Islam. Banyak perlawanan-perlawanan yang dihadapinya. Beliau harus hijrah, harus sembunyi sembunyi dari masyarakat yang menantang ajarannya. Banyak rintangan yang beliau hadapi. Beliau harus menahan rasa lapar, rasa capek dikejar musuh dan sebagainya. Namun dalam perjuangannya tersebut juga tidak kalah banyaknya mukjizat-mukzizat yang beliau terima. Semua rintangan yang beliau alamai ada jalan keluarnya. Semua masalah yang beliau hadapi ada penyelesaiannya. Kisah-kiah ini merupakan penebal emosi keagamaan bagi masyarakat penikmat Sarafal Anam.

Selanjutnya yang dimaksud dengan fungsi estetis di sini adalah funsi seni pertunjukan Sarafal Anam yang terkait dengan keindahan. Keindahan pada pertunjukan Sarafal Anam dapat dilihat dari bentuk rima, diksi dan gaya bahasa yang terdapat pada syair yang dilantunkan oleh para pemeran. Fungsi estetis dalam pertunjukan Sarafal Anam dapat dirasakan dari lantunan syair-syair dengan irama yng khas dengan diiringi tabuhan rebana. Lantunan Syair-syair dengan irama yang khas dan diringi dengan tabuhan rebana tersebut memiliki nilai keindahan tersendiri dalam pertunjukan Sarfal Anam.

\section{SIMPULAN}

Berdasarkan hasil analisis data dan pembahasan penulis simpulkan bahwapertunjukan seni Sarafal Anambagi masyarakat suku Lembak pada acara pernikahan di kelurahan Pagar Dewa Kota Bengkulu memiliki makna solidaritas, kebersamaan, dan hiburan sebagai pelengkap kegembiraan terwujudnya pernikahan anak dalam suatu keluarga. Melalui seni pertunjukan Sarafal Anam nilai budaya yag terkait dengan solidaritas dan kebersamaan akan selalu terpupuk dengan baik. Khusus bagi pemyelenggara, pelaksanaan pertunjukan seni Sarafal Anam yang mereka selenggarakan adalah secara tidak lansung untuk memberitahukan kepada masyarakat lingkungan bahwa anak yang akan menikah adalah bujang dan gadis. 
Pertunjukan seni Sarafal Anam pada acara pernikahan masyarakat suku lembak di Kelurahan Pagar Dewa Kota Bengkulu juga memiliki beberapa fungsi, yaitu (1) sebagai hiburan,

(2) fungsi pendidikan, (3) fungsi penebal emosi keagamaan, (4) fungsi estetis. Fungsi tersebut melekat pada unsur pokok dalam proses penyelenggaraan Sarafal Anam, yaitu pemeran, penyelenggara dan penonton.

\section{DAFTAR PUSTAKA}

Anwar. (2006). Makna Sastra Lisan. Surabaya: Usaha Nasional.

Atmazaki. (1993). Analisis Sajak Teori Metodologi dan Aplikasi. Bandung: Angkasa.

Djajasudarma. T. Fatimah. (1993). Semantik 1 Ke Arah Ilmu Makna. Bandung: Eresco.

Djojosuroto. Kinayati. dkk. (2000). Prinsip- Prinsip Dasar Penelitian Bahasa dan Sastra Bandung: Nuansa.

Endraswara, Suwardi. (2003). Makna Sastra Lisan. Bandung: Angkasa.

Gunarwan, Asim. (2007). Pragmatik Teori Kajian Nusantara. Jakarta. Universitas Atma Jaya.

Hadiati, Diah Nur. (2016). Bentuk, Fungsi, dan Makna Upacara Ritual Daur Hidup Manusia pada Masyarakat Sunda. ADLN-Perpustakaan Universitas Airlangga.

Hamidin, Muhammad. (2016). Bentuk, Fungsi, dan Makna Mantra Ritual Upacara Kesambu Masyarakat Muna Kecamatan Katobu Kabupaten Muna. Jurnal Bastra. Volume 1, Nomor 2.

Hestiyana. (2014). Fungsi dan Makna Sastra Lisan Banjar Mahalabiu. Jurnal Bebasan Volume 1. Nomor 1.

Jauhari, Heri. (2018). Makna dan Fungsi Upacara Adat Nyangku Bagi Masyarakat Panjalu. Jurnal Al-Tsaqafa Vol. 15, No. 02 Desember 2018 hlm. 197-210.

Kartika, Dewi. (2014). Bentuk, Makna dan Fungsi Kuda Lumping Turonggo Tri Budoyo di Desa Kaligono Kecamatan Kaligesing Kabupaten Purworejo. Jurnal. Volume 4. Nomor 1.

Karyawanto, Harpang Yudha. (2017). Fungsi dan Makna Seni Jemblung Murtadho dari Jawa Timur. Jurnal Budaya Nusantara. Volume 1. Nomor 1.

Koentjaraningrat. (2002). Pengantar Antopologi. Jakarta: Rineka Cipta.

Setiadi. Elly M, dkk. (2012). Ilmu Sosial Budaya Dasar. Jakarta: Kencana.

Sorayah, Yayan. (2014). Fungsi dan Makna Mantra TandurDi Desa Karangnunggal Kecamatan Cibeber Kabupaten Cianjur. Jurnal Bahtera.Volume 2.Nomor 2.

Moleong, J Lexy. (2009). Metodologi Penelitian Deskriptif. Bandung: Remaja Rosdakarya.

Tarigan. Henry. Guntur. (1988). Pengajaran Semantik. Bandung: Angkasa. 
Turaeni, Ni Nyoman Tanjung. (2011). Bentuk, Fungsi, dan Makna Tradisi Lisan Mabebasan dalam Upacara Keagamaan di Jawa Timur. Jurnal Metasastra Vol. 4 No. 2 Desember 2011 hlm. 171-180. 